\title{
The Social Engineering Model to Safe from Extinction of Subak Farming System in Bali - Indonesia
}

\author{
Indah Susilowati ${ }^{1}$, Made Ika Prastyadewi², Deden Dinar Iskandar ${ }^{1}$, and Waridin Waridin ${ }^{1}$ \\ ${ }^{1 /}$ Lecturer at the Faculty of Economics and Business, Diponegoro University \\ 2/ Ph.D. student, at the Faculty of Economics and Business, Diponegoro University
}

\begin{abstract}
Tourism plays as the most important sector in Bali and its surrounding. With an excellent local wisdom maintained by their people to run the business in tourism at a single fraction of their breathing. But with the challenge of time and the actual demand, it is hardly to defend the local wisdom of farming system in Bali called as Subak for the value of culture and ecology versus the economic value of land for tourism needs. The land of farming with Subak system in which usually supply for the beautiful of paddy field terracering scenery is decreasing from time to time in Bali. In 2016 recorded for $915 \mathrm{Ha}$ of Subak and it gone for about $138 \mathrm{Ha}$ Subak in 2017.
\end{abstract}

There were three types of Subak selected in this study: traditional, modern, and world heritage categories. The study located in Subak Pulagan of Gianyar district, Bali. Public Good Games experiment, descriptive statistics and transaction cost were used to analyse the data gathered with qualitative and quantitative approaches (mixed methods). It is expected a model of social engineering could be developed effectively to internalize the externalities of Subak. Thus, the formulated model will be used for consideration in decision making to the local government and society to maintain the sustainable existence of Subak farming system.

Key-words: Subak, farming-system, internalization, externalities, extinct, Bali, Indonesia. 